\title{
EDITORIAL
}

\section{CIÊNCIA COMO VETOR DE DESENVOLVIMENTO}

Clóvis Ultramari ${ }^{1}$

O início da nova década do século XXI indica o aprofundamento dos desafios concernentes ao processo de desenvolvimento das regiões brasileiras. A nova realidade sanitária imposta pela pandemia do COVID 19 implica transformações no cotidiano e para o futuro quanto à organização das atividades produtivas, à pesquisa científica e ao planejamento e efetivação das políticas públicas. $\mathrm{O}$ fator comum é o papel da ciência quanto às medidas de prevenção ao vírus, à produção de imunizantes e o aperfeiçoamento das ações adotas, tais como o ensino e o trabalho remotos, considerando a mediação necessária entre eficiência e preservação da qualidade de vida.

Nesse cenário, as Ciências Humanas e Sociais Aplicadas têm um papel ímpar. O destaque conferido às Ciências da Saúde não deve secundarizar a necessidade premente de considerar como avaliar e incorporar as experiências de 2020 para os processos de desenvolvimento. A pandemia do COVID 19, e suas consequências, não pode ser percebida como uma exceção histórica. A conexão pertinente às cadeias produtivas globais, o intenso trânsito internacional de pessoas e mercadorias e a redução agressiva dos biomas de cada região do planeta implicam uma possível recorrência de emergências globais, cujo enfrentamento demanda a coordenação internacional e, simultaneamente, atenção às peculiaridades regionais para o sucesso das medidas que podem ser tomadas nesse cenário.

O conhecimento produzido nas últimas décadas acerca das relações entre sustentabilidade ambiental, social e econômica e desenvolvimento pode amparar políticas públicas aptas ao enfrentamento dos próximos desafios. Porém, para sua efetivação se faz necessária ampliação da comunicação entre Estados nacionais, sociedade e universidades. Destaca-se a complexidade para a efetivação e avanço desse diálogo, considerando as diferentes perspectivas e realidades nacionais, bem como suas distintas inserções na dinâmica da divisão internacional do trabalho.

No presente, o Brasil está distante de combinar a efetiva aproximação entre os entes da federação e os demais setores da sociedade para enfrentar, de modo coordenado, os problemas ambientais, sociais, econômicos e sanitários. Tal condição tem efeitos heterogêneos, com impactos específicos sobre cada classe social. A brutal concentração de renda, bem como as disparidades regionais, tendem a persistir e se agravar, especialmente com a precarização do trabalho e o recuo da renda dos trabalhadores frente a renda do capital. Assim, por exemplo, a minoração dos efeitos da inaceitável insuficiência de saneamento básico tende a permanecer, bem como outras situações que caracterizam o desenvolvimento desigual e combinado de países como o Brasil e sua inserção na dinâmica internacional do trabalho.

A erosão da imagem e da credibilidade internacional brasileira foi acentuada em 2020, diante do negacionismo em relação à ciência e da necessidade de coordenação internacional para o enfrentamento da pandemia do COVID 19 e das calamidades globais. Destarte, projeta-se o afastamento do país dos avanços da ciência em suas múltiplas dimensões, fragilizando ainda mais o

\footnotetext{
${ }^{1}$ Editor Chefe da G \& DR. Economista, Mestre em Economia pela Pontifícia Universidade Católica de São Paulo (PUCSP)Doutor em Engenharia Aeronáutica e Mecânica pelo Instituto Tecnológico de Aeronáutica (ITA). Pós-Doutor em Gestão da Inovação Tecnológica pelo Instituto Tecnológico de Aeronáutica (ITA). Coordenador Geral e Professor do |Programa de Pósgraduação em Gestão e Desenvolvimento Regional da Universidade de Taubaté (UNITAU). E-mail: edsonaaqo@gmail.com.
} 
processo de desenvolvimento nacional. Tragédia duplamente ressaltada com o encerramento das atividades da Ford no Brasil. Primeiro, pela dependência econômica e tecnológica do capital internacional e, segundo, em razão da saída da multinacional do país sem consulta e negociação prévia com o Estado brasileiro.

Cabe aos pesquisadores brasileiros persistir na produção de conhecimento, fundamental para a inovação e o desenvolvimento, bem como ampliar a comunicação científica, somando à divulgação científica a luta por fundamentar as políticas públicas em ciência ao invés de medidas inócuas e difusas, para o início da redução das assimetrias regionais brasileiras.

Esta obra está licenciada com uma Licença Creative Commons Atribuição 4.0 Internacional. 